\title{
The Character of an Effective Nation Leader According to the Old Testament to Prepare the Young Leaders of the Present Are Visionary and Effective for Urban Communities(Main Samples of the City of JAKARTA and its surroundings)
}

\author{
Nuah Perdamenta Tarigan ${ }^{12}$ \\ \{nuah.tarigan@binus.ac.id\} \\ ${ }^{1}$ Character Building Development Center, Computer Science Department, School of Computer \\ Science, Bina Nusantara University, Jakarta, Indonesia 11480 \\ ${ }^{2}$ Chairman, Gerakan Peduli Disabilitas dan Lepra Indonesia (GPDLI).
}

\begin{abstract}
We form our buildings, but after that, they will shape us (Winston Churchill). "There are no plans; then the future will also not exist." for the city of Jakarta too. Years later, Ali Sadikin confirmed his policy: "I acted realistically and was not hypocritical. When I became Governor of DKI Jakarta (1966-1977), he agreed to legalized gambling because the city government did not have enough funds" Looking at the situation in Jakarta from time to time the time is getting worse the author has the desire to do research that is more profound and more widespread and will begin since 2012. So much degradation has occurred in Jakarta for several years, especially with the fading and alienation of humanity and the lives of its people, especially young people in Jakarta which in the future will be very important in the progress of the Indonesian people, especially Jakarta and its surroundings. Before everything is too late - The author takes a small step to develop and transform this situation with an empathetic management and leadership approach to change the existence of young people and future generations of Indonesia. The plan is to look at some literature relating to Management and Leadership and an in-depth approach to verses and stories in the Old Testament that are very relevant to this context. Towards what is aspired by our Father of the Nation, even more so, the Almighty God, Our Father Who Is In Heaven
\end{abstract}

Keywords: Effective Nation Character Building and Leadership, Young generation, Jakarta and fringe areas, Management, Leadership, New Testament or Bible.

\section{Introduction}

The author limits this dissertation from the time the reforms were rolled out and occurred in Indonesia, the riots in Jakarta and Indonesia. in general, indicate that changes began to take place from 1998 to 2008 and compared with the new leadership implemented by Jokowi Ahok since 2012/2013. DKI Jakarta is more concerned with the designation and situation in which Jakarta is called miniature Indonesia itself, so that it will represent the attitude of Indonesian people as a whole. The figures displayed also do not present all, but we limit the initial DKI Governor named Ali Sadikin, his leadership and bringing the welfare of the capital at that time 
still remembered by the old generation compared to the period 1998 to 2008 . The restrictions that I developed here also is on social political or social leadership and does not touch other spaces. The hypothesis will be the author convey in the next section after limiting the problem. The patron of the author can take in this section is the Old Testament, leadership under the Prophet Moses, besides the Prophet Moses was a figure who carried a spiritual mission, but he was also a social and political leader, who fought to achieve His vision of God to bring the Israelites to the promised land of Canaan.Today's young leaders who are visionary and effective in Indonesia The Young Leaders of the Present Are Visionary and Effective in Indonesia at this time still not visible. Indeed there are some that stand out, but the authors cannot say they are leaders, but if there are many leaders or President Directors, Directors, Managers, and other leaders, especially those related to management. Second, today's young leaders are visionary and effective in the City. Today's young leaders who are visionary and effective in urban areas at the moment are still not clearly visible, indeed there are some that stand out, but the authors cannot say that all of them are leaders need to have more in-depth research and focus in order to see an approach that true and will be useful for the future of the city. Third, the impact of global change on the leadership of today's young leader nations that are visionary and effective in the Nations is still not clearly visible, indeed there are some that stand out, but the author still cannot see clearly, this is important because soon the countries in Asia and the rest of the world will start with what is called a free market, this condition will begin around 2 years less than now, namely early 2015 . How will this increasingly extreme global change respond, depending on how we foster future leaders. Therefore the time is immediate and urgent, not only important. Fourth, the character needed to build sustainable leadership, today's young leaders who are visionary and effective in Indonesia at this time still do not clearly see how the character of leaders who are able to build sustainably, not only act as managers, but especially from those who are leaders.

\section{Literature Review}

\subsection{Differences in Leadership and Management}

At first glance, there doesn't seem to be a difference between leadership and management. The person doing the task is called the leader and manager. All look the same from the side of the function, namely someone who has a position to lead and organize an organization. There was a controversy about the difference between leadership and management. Actually to know the difference is through the process and the results that occur. How to distinguish leadership and management from core processes and what is the expected results. Bernard Bass, a leadership expert concluded that leaders are managing and leading managers. The following is a list of differences between leaders and managers:

Table 1. Differences between Leaders and Managers

\begin{tabular}{ll}
\hline \multicolumn{1}{c}{ Leader } & \multicolumn{1}{c}{ Manager } \\
\hline Innovated & Managed \\
Developing & Sustain \\
Inspire & To Control \\
Having A Long-Term Outlook & Having A Short Term View \\
Ask What And Why & Ask How And When \\
Bring Up & The Start \\
Do Something With Right & Do Something Right \\
\hline
\end{tabular}




\subsection{Leadership Style}

The leadership style contains an understanding as a manifestation of the behavior of a leader concerning his ability to lead. The embodiment usually forms a pattern or shape. This understanding of leadership style is in by the opinion conveyed by Davis and Newstrom which states that the overall actions of leaders as perceived or referred to by subordinates.

The leadership style represents the philosophy, skills and attitudes of leaders in politics. Leadership style is a behavior pattern designed to integrate organizational goals with individual goals to achieve certain goals. Whereas according to Tjiptono, leadership style is a way used by leaders in interacting with their subordinates. Another opinion states that leadership style is a pattern of behavior (words and actions) of a leader that is felt by others.

Everyone has a leadership style that is different from one another. According to Rensis Likert, individual leadership styles within the organization can divide into; First, exploitative, which is to extort subordinates, subordinates must achieve goals, if not punished. Second, authoritative, which is hard on may not comment on orders. Third, consultative, that is, asking for the opinion of subordinates, the purpose outlined, general orders issued after discussion. Fourth, Participatory, where goals are there while decisions occur. Within the organization.

\subsection{Character of Nation Leaders}

Understanding the Character of the Nation Leader is very broad because it covers all aspects of leadership, not only the social and political but also includes society. So many studies lately around the world, the proliferation of training centers that have tapped the problems of leadership in Indonesia and globally prove that leadership is not a talent that has existed since childhood but is a process towards perfection that is better than before. Some of the entries and writings below will explain further about some of the theories and contents of the book written by Peter Northouse which the author said above, from what the word leadership itself means to some leadership notions from some of its approaches, along with books which supports it.The textbook written by Peter Northouse is very good, and easy to understand, both by academics and business and public life. Besides UPH the author taught these materials for other campuses, such as Bina Nusantara University, Jakarta and President University, Cikarang (West Java) and saw their benefits in the lives of young people in Jakarta and surrounding areas. Thousands of students have listened and facilitated this leadership teaching, and paramount and comprehensive book. The approach taken is indeed not merely a theory written in a book, but also by using some correlations with other subjects such as character development, self development, interpersonal development, spiritual development and professional development.

There are two approaches to leadership. The two approaches are approach to character and approach to behavior, as follows:

1. Approach with Character.

The approach to character is one of the systematic attempts to learn leadership. This character focuses exclusively on the leader; a) what the leader has; b) who owns these characters; c) conduct research on the autobiography. Based on the biographical background of a leader, an approach with characters looking for the dominant of leaders influences their leadership.

2. Behavioral Approach

The approach through behavior focuses on what a leader will do and how they do it, there are seven styles of doing leadership using this approach; a) Authority Compliance 
Management: Leaders who suppress at work. How to develop communication with the subordinates and instructing them to do their duty; b) Country Club Management: this type of leader is very focused on it so that they are not concerned with their duties; c) Impoverished Management: Leaders in leadership styles like this are passive leaders, they tend to create a distance between them and their subordinates; d) Middle of the road management: leaders with this style have a balance between their attention and tasks, many of which apply this leadership style; e) Team management: this is an ideal leadership style, he maximizes focus on work and focuses on subordinates, tries to touch the hearts of others and on the other hand tries to reach the goals of the organization to the full; f) Paternalism / Maternalism: Leaders with this style emphasize loyalty and obedience from their subordinates, expecting them to do everything for the organization; g) Opportunism: this style focuses on leader's personality, there are no constitency.

The study of leadership was classic and gave much inspiration to so many experts, starting from the great men who assumed that the leader was born, then continued with the nature theory which tried to identify leadership based on the traits inherent in the successful leader. Then the behavior analyzing successful leadership is determined by situationbehaviors, and contingency theory must focus on conditions in which it is carried out. This is the outline of it that has developed so far.

However, at this level of theory not a single theory can explain what theoretical concepts are suitable for the situation of conditions that exist in Indonesia as explained by situational theory or contingency. There is a concept that raises from a local based on the Indonesian philosophy of life, namely Pancasila. Pancasila is the philosophy of life of the Indonesian people, where the lifestyle of the people develops the values in the Pancasila. The Meaning of Pancasila Leadership is leadership that brings the community to their awareness, nation, and state based on Pancasila and UUD ' 45.

Characters have diverse meanings, however in the context of this research we will limit as a person and relationship between people, and not be developed in a sense to things that are vertical in spirituality and so will not alluding to matters of leadership, but more to the context of leadership that is of a horizontal nature, between fellow humans and their environment, related to biblical approaches, especially the Old Testament. More specifically, Prophet Moses. Many colors that occur in his life, grief, ups and downs, which are very relevant to the situations and conditions of humanity and leadership today. Nation Leadership Character here is if someone can lead a group of people in a large size, more than the context of the local leader which is very limited and in small numbers. It said that it had exceeded the usual, not only hundreds and thousands, it has even reached millions.

The leadership crisis has occurred everywhere, including the leadership of Christian spiritual organizations, so effective understanding here will be very important and will distinguish it from other approaches that use the power of power and violence, but the opposite here will be more the participatory approach that has been conveyed in the leadership theory previously leads to the servant leadership approach. We will discuss it step by step towards understanding and openness for future development. The leader who will focus on the community leaders that can be accommodated by all members of the Indonesian community, especially in this context, is that the Jakarta community is so plural and diverse, with this focused approach that the dissertation will not be too broad to spiritual leadership and so forth. The Prophet Moses, who had experiences across cultures, could be a representation of what the author had written before, "thrown away" from the land of Egypt and lived in the Pharaoh's family making Moses small until his youth came into contact with things that were cross-cultural, making Moses unfamiliar with the situation. Although he finally became the 
leader of his nation but the education he had received while with the Pharaoh's family made the Prophet Moses confident and brave in making a decision, there was even a time when he took action without consulting God. The crisis experienced by the world and Indonesia today can be said to start from the leaders in this case are leaders who are responsible for public and community problems. The quality of leadership of a nation can be measured by the conditions of the people who are at the bottom, the marginal and the minority, where they are not empowered to be independent and prosperous. This is because the nation does not have capable leadership morally and technically.

The biggest challenge is to create public awareness so that leadership needs are felt and understood by their significance. Sen Sendjaya who wrote some things as follows:

Areas where the process of "adoption" and "abortion" include vision, accountability, and empowerment and serving leadership; 1) Vision is a biblical concept that shows God's direction and direction to His servants. Not a few churches have visions, but only limited rhetoric. The church leader did not know which direction he was leading the church. The corporate vision gives direction and creates performance standards for the company and builds commitment and passion for life for the individuals who work in it; 2) Accountability. Accountability keeps leaders in sharp influence but has long disappeared from Christian leaders, both in the church and outside the church. In contrast, the business world has long built accountability and integrated it into their systems; 3) Empowerment. Empowerment is a biblical concept. The gifts God gives to believers are to empower the body of Christ (Ephesians 4:12). But what happens among Christians is the process of fooling. In the business world, various empowerment efforts are carried out. Every individual who works and treated as the most valuable company asset, for the leaders of the company; 4) Leadership serving. The business world adopts a leadership pattern, while the church abuses it even though the leadership is a biblical leadership philosophy. Christian leaders discard leadership principles that the Lord Jesus taught and modeled. While the business world uses this philosophy to be the foundation for building confidence and for building excellent performance.

Various global companies, realize a solid vision, build accountability, empower employees effectively and apply the leadership concept that serves. They have adopted biblical leadership concepts and have proven effective. While God's people, especially Christian leaders, even abused it. Related to the character of the nation's leaders who can effectively carry out their duties and in accordance with the rules of leadership, and in line with the Word of God found in the Bible, especially in the Old Testament. in this context the author focuses only on Prophet Moses who has cross-cultural and colored experience in his life. We see that now the leadership has deteriorated everywhere, including in Indonesia, it's time for young people to be prepared from now on in order to become the future visionary leaders of the future, of course in the context of urban communities in this case Jakarta Raya, which even surpasses its administrative area, which affects the lives of the cities and regencies around it, the commuters on a daily basis in Jakarta make this city very busy and eventually become a dilemma of its own in handling social, cultural, humanitarian, political, economic and other problems. Young people are often ignored in the city development process and are often not considered in building the Jakarta community. The experience and existence of the city of Jakarta today is also not far from what is experienced by cities and districts in Indonesia, in the perspective that we build is from issues related to the leadership of the city of Jakarta. What must do the future, it is not enough with plans and budgets for training.

Because his father gave him a beautiful robe when he was a child, indicating that he was the heir of God's promises to the family (Genesis 37: 3). Often in the life of a leader there is a 
time when they try and enter a road before God's time and before they prepared, as happened of Moses who then fled to the desert and was cared for by his in-laws. But what happened of Moses or Integrity can be said to be an example for leaders of all time, because he has the character of honesty, sincerity, likes, peace and always has the right responsibilities by God's plan.

As the Word of God in Psalm 37: 37 "Pay attention to those who are sincere and look to those who are honest, for those who are peaceful will have a future". We all want that we can live in sincerity, peace, honesty and peace. We want to be sincere, honest and peaceful because with such an attitude, surely the future of our church will be bright and the future of our nation. But, precisely because of that we still need to be critical of the intentions of sincerity, honesty, and reconciliation. Because we have to connect with the perspective of our own interests. Because not only angry with the wicked, but the wicked are also angry with the righteous, so with this we must be careful as Emanuel Gerrit Singgih said, "where there are righteous and wicked people, or where there are people who consider themselves the righteous and others are wicked, there is always an atmosphere of conflict and not peace ".

\section{Methods}

This research is to express and recognize leadership patterns desired by citizens, especially residents of the Capital City of DKI Jakarta. Then, based on these findings, efforts have been made to propose a servant leadership.

Regarding the quality of the desired leader aims to answer the needs and problems of DKI Jakarta (Jakarta Municipal City). These factors need to be considered to recognize patterns of needs and faced by Jakarta. Several factors in answering the problem and the need to produce effective leadership are, a) behavior; b) preference assessment and; c) demographics.

The leadership pattern desired by citizens, especially residents of the Capital City of DKI Jakarta, is effective leadership. Several factors in answering the problem and the need to produce effective leadership are, a) behavior; b) preference assessment and; c) demographics. Through good character leaders, character leaders who recognize the needs and problems faced by DKI Jakarta. While the preference assessment of leaders is leadership-tested leaders, leaders who understand young people, leaders who do not act discriminatively, idealistic leaders and leaders who are not complicated, It will produce effective leadership for Jakarta Municipal City.

\section{Result and Discussion}

Based on the development of leadership concepts, ranging from the trait approach to behavioral, situational and transactional and transformational, the servant-leadership leadership has some similarities with the transformational leadership. According to transformational leadership experts transformational leadership is more proactive and more effective in motivating subordinates to achieve better performance. Transformational leaders are more capable and more sensitive to their environment to further disseminate strategic goals that are able to capture the attention and interests of their subordinates. The followers of transformational leadership show a higher commitment to the organization's vision and mission, willingness to work harder and also very important is to have higher trust in the 
leader and show a higher level of cohesion. According to Bass \& Avalio (1994) transformational leaders achieve superior results by influencing their subordinates through 4 ways, namely 1) idealized influence (being a model and giving rise to a personal identification process), 2) inspirational motivation (creating team spirit and creating unity of vision), 3 ) intellectual stimulation (encouraging the ability to think, creative problem solving to subordinates) and 4) individual consideration (doing coaching - development by considering the conditions. Based on the characteristics of transformational leadership, the authors assume that the concept of servant-leadership has several. Characteristics of healing, stewardship, and commitment to the growth of people/others as well as building community on Servant Leadership similar to individualized consideration in its efforts to develop others, behave in full struggle for the interests of the wider public. Of course, this behavior requires some strengths from personal values (personal values) that can encourage the emergence to change the condition of a large group of employees or people from fewer to be in a much better. Based on the concept of value from Rokeach (1978), values that become goals and values that are ways to achieve goals are referred to as Terminal Values and Instrumental values, while Schwart \& Bardi (2000) refer to them as Motivational Values.

In the concept of servant-leadership, power or power that takes place is not personal (for personal gain) but rather institutional (or for the benefit of many people). Every leader action or behavior that strives continuously to serve the needs of the wider community, will be seen and felt by followers. All acts of leader service will be a role model that can stimulate and motivate follower behavior to bring up actions / service behaviors for other people or others. Thus the act of service carried out by the leader to his followers will create a kind of 'domino effect' on a group of followers who will also pioneer service for other parties.

Servant-first leader behavior always defends the interests of subordinates and the wider community and results in the development of prosperity for followers (in transformational leadership is a feature of idealized influence and inspiration motivation) over time will also lead to extraordinary trust and respect towards the leader. Managers in the Disparbud and tourism service industries that are directly in contact with tourism consumers need to be aware of the need to show servant-first actions not leader-first. In more complex problem situations, the characteristics of transformational leadership intellectual stimulation that encourages subordinates / followers to obtain creative solutions, of course, requires adequate thinking skills in leaders. In the servant-leadership concept, this is related to the characteristics of conceptualization and foresight, where leaders think about and formulate and anticipate short, medium and long term achievements. Conceptualization is characteristics of traits, namely the ability to think conceptually and anticipatory thinking about changes or how groups of followers transform in the future. Regional Governments, especially Jakarta Municipal Cty, have the function of regulating and managing tourism in an area, the manager's ability to conceptualize and anticipate medium-long term planning on the development. It is related to the intellectuality of the stakeholders in the Provincial Government accompanied by the characteristics of persuasion must be able to convince other relevant agencies (Public Works Agency for transportation, etc.) to support planning implementation. In urban environments, foresight characteristics and conceptualization of managers are needed for the development and marketing of services (and products). The listening, empathy, and persuasion are tools in the form of interpersonal skills that are needed by leaders in communicating when motivating followers, in expressing high- performance expectations for followers and in conveying the organization vision clearly and convincingly. Expectations of service performance towards followers indicate that leaders demand quality and prime service behavior on followers. With persuasion capabilities, leaders can provide convincing explanations to followers about the 
high achievement picture that individuals and organizations will achieve in the future. Thus individual followers will also understand what their role is and have a sense of hope for a better future. Related to the distinctive characteristics of government organizations whose employees are Civil Servants, managers need to demonstrate these interpersonal skills as a tool to influence and manage HR within the government as well as to influence stakeholders or decision makers in other relevant agencies who are also responsible for urban development.

\section{Conclusions}

Based on the results of the research and supported by the discussion in this dissertation. Finally, the author is at the end of writing this dissertation. For this reason, the writer makes a theological reflection, then draws conclusions and suggestions for the church, as follows:

\subsection{Theological Reflections}

The phenomenon and condition of our national leadership today should make us more aware that at this time there has been a process of degradation of the quality and partisanship of the people and the constitution which is increasingly towards the nadir. The present context shows the real and objective things that have happened. Our current national leadership can be said to be very weak and not by the mandate of the Indonesian people. Corruption has become entrenched, violations of law and human rights are everywhere, problems and dangers of disintegration are critical, economic policies are not pro-people, and various other has arisen. Everything happened, one of which was caused by the crisis of leadership and the absence of examples from leaders who did not animate and were not based on Pancasila and in the context of Indonesia, there were fewer visionary leaders, including Christians.

Leaders and leadership are two different things. Talking about the Leader, we will talk about the individual or the person while is how the style or the way and what the leadership is. Anyone whose leader can be as great if he has the character and leadership spirit that is strong, systematic, visionary and siding with the people and has its characteristics. But leadership that is not strong will make any leader as not be able to lead well, visionary, and certainly trustworthy because of the absence of leadership style that makes him strong enough to survive as a leader

Pancasila-based leadership released from the conceptual building of the five precepts in it. How is the divinity placed first and foremost alias as the basis of morality?. As a causal precept (source from another issue) then the leader in question here is inevitably a leader who has God, is moral and carries out his existence in the world for the welfare of nature and the people in it. Leaders who become servants for others. In the discussion of modern leadership, the term "spiritual leadership" is famous, authentic and practical leadership, morality leadership, or prophetic leadership. At the core of all that, that leadership is a mandate and gift from God and also must be accountable to Him with evidence and results, namely human welfare and nature. From here, Pancasila-based leadership has closed the door for godless leaders, atheists, and agnostics and of course those who do not side with the people.

The second precept is a just and civilized humanity principle, as one of the tools/ways to achieve the goal of state and nationhood. The nature of the universal humanism championed by all nations through human rights is also the focus of leadership-based. The goal is paramount how to make this humanity manageable in line to civilized humanity. Worthy and 
proper for living humans. Who inevitably, this leader must place personal, group and other eccentric interests under universal human values.

The third principle is the principle of unity, which is also a tool / way to achieve the goal of state and nationhood. In the discussion of leadership between goal oriented and process oriented, Pancasila-based emphasizes the spirit of unity which means continuing to process. It would be useless if the goal was achieved but eventually scattered or disintegrated (read: disbanded) because of the breakdown of unity. In the context of the current leadership, we understand this as a leader as a solidarity maker. Those who are able to put themselves together are those who can set foot everywhere but still have one control, which can be a symbol of togetherness and unity.

The other precept is about democracy or Indonesian-style democracy, which is the purpose of why we have a state and a nation. Leadership based on this basic principle is capable of building a democratic system, both in the aspects of politics, economics, culture, education and so forth to achieve national goals in a democratic and dignified manner.

The fifth precept is about social justice which is our ultimate goal for the state. In essence, the Pancasila Leadership built by not only about legal, not just economic, political, justice in education, but which has a high challenge of social justice. Fair but social dimension. Fair but siding with those who are marginalized or marginalized.

In the context of modern leadership, we often want to find out how leaders who are propeople, pro-indigenous, pro-poor or poor, pro-welfare, pro-poverty alleviation, cheap and quality pro-education, free pro-health. How the country he leads is like a family that guarantees social justice for his children so that the poor and neglected children even though they are not neglected and maintained by the State by Article 34 of the 1945 Constitution.

\subsection{Pancasila Based Leadership}

It is quite difficult when you have to say names or people when you choose who is the leader who can be said to have the spirit of Pancasila. He must have a lot of names in the future that we can nominate, so whoever they are, all of them will fight for the establishment of Pancasila values. Not even claiming to be the Pancasila leader, but its essence and recordings cannot prove that he has championed Pancasila values in his life in various fields of life.

It is better for people who feel they deserve to be leaders who want to run for Pancasilabased leaders. Even if they have not been able to appreciate it, it is appropriate for the sons or daughters of the mother who have the character and competence who have the Pancasila leadership spirit to be given the opportunity to come forward and show evidence that the Pancasila is still there and always ready to contribute to Indonesia. Seeing the condition of the Indonesian nation which is currently very crowded with a variety of problems, we must return to the nature of the national struggle, which is again to make Nationalism based on Pancasila as the motor. We must try so that the national resilience will show its strength and make the Indonesian nation-high achievers. This is even more important because it turns out that between now and 2035 Indonesia experiences a demographic dividend or a "population bonus". This happens because in this period the number of people in productive age far exceeds those in less productive age. This, if properly utilized can produce high welfare for the Indonesian people. Conversely, if there is no such effort, it will make the population destructive in large numbers. This symptom has now begun to appear with the amount of violence in various aspects. 
The National Leadership that carries out National Management effectively begins by changing the attitude of the nation's leader or elite which is now widespread, namely the attitude that is less concerned about the future of the nation and prioritizes personal interests. Reinforced the National Struggle and Pancasila by giving an example that raises confidence in all nations towards a future full of progress and prosperity. The important thing to show is that attitudes are not only clever and talkative but also accompanied by real actions to make the real reality talk. The strong enthusiasm in showing real deeds raises the struggle that is very much needed by the Indonesian people to face humanity who are experiencing various changes in many aspects of life.

With quality management capabilities that are pro-people, we will be able to design various initiatives to make national potentials a real power starting with Human Resources who are presenting Population Bonuses over the next two decades. It is clear that Education is a very important tool, both to establish Pancasila as a National Identity and to develop various knowledge and skills. Education also strengthened the national Character so that step by step we leave the character and nature of the nation that is negative. Therefore, quality education is paramount, both in the form of empowerment in the family environment, in the school environment and continuing education in the community. By organizing quality education in all aspects of life will be realized very valuable human resources and bring forth sustainable (Pancasila) based leadership in an effort to create Progress and Welfare together."Leadership" is a transformational part of holistic education and must enable "Life-Changing Experience".

Today the world is experiencing a leadership crisis because too many organizations led by people who do not have leadership competence; even some of them have character defects. Meanwhile there is a sad global megatrend, especially for church circles, where the secular business world is increasingly aggressively adopting biblical leadership principles and patterns (even though they are not aware of them), and conversely, the church aborts those principles and patterns. In short, business is increasingly biblical, and the church is increasingly secular.

This tendency is in at least four areas, namely aspects: (1) Vision, (2) Accountability, (3) Empowerment, and (4) Serving Leadership. Back and forth we see many churches that do not have a clear vision, even if there is only limited rhetoric. While on the other hand, the business world has many corporations with a good standard, that not only directs and creates performance standards, but also a vision that builds commitment and enthusiasm for every individual working in it. In the second area, we are familiar with various types of audits and standards in the business world, which reflect the spirit of accountability, so that the company's operations do not harm society and the environment. On the other hand, declined in the church environment. In the third area, many parties indicated a lack of empowerment within the church environment, often people were only treated as patients who came to stress clinics that needed psychological-religious therapy. Whereas the business world is enthusiastic in empowering, marked by the strength of Training and Development as one of the keys to success in many multinational companies. In the fourth area, it appears that the business world began to adopt biblical leadership patterns, namely servant leadership, while the church to abort it.

The crisis and irony of church leadership was also marked by the fall of church leaders due to various factors, namely: financial, sexual, relational, intellectual, and emotional. Therefore it is necessary to look for ways or strategies that can prevent the fall of the leader, as follows: (a) acknowledge our vulnerability to the temptation of sin, (b) keep away from things that have the potential to make us fall, (c) establish accountability relationships, (d) maintain the harmony of husband and wife, and (e) maintain spiritual discipline. 


\section{Suggestions}

These changing times in leadership are demanding that the church take a clear position on issues of change. Church leadership management is a tool that can be used by the church in presenting tangible changes in service to God's people. Some of the challenges faced by church leadership are planning in the context of service effectiveness is a problem for church leadership today, demands a life is not blemish before God and the church and the spirituality aspect of a leader. In answering this problem, the church must begin to carry out strategic planning to plan all activities and activities carried out with planning by using all the resources they have and the goals and objectives to be achieved on an ongoing basis. In addition, the character of the spiritual leader must be an example and an example for the church he leads accompanied by the spiritual qualities possessed by the church leader.

Leadership that is supported by the spiritual quality of leaders will shape that has a high value of personal commitment to Christian ethics and leadership integrity. Leadership in the 21 st century becomes increasingly complex, where the three elements that change it, namely leaders, followers, and contexts, experience and significant changes, moreover they influence each other so that the level of complexity becomes increasingly high. Various global scale changes have shaken the existence of leadership in sectors both in companies, universities, churches and other institutions. The implication of the duties and responsibilities of leaders becomes increasingly severe, even for Christian leaders to be two or three times more complex, because and overshadowed by ideal biblical standards.

\section{Acknowledgement}

The research we submit here is the result of the research that we made for the completion of my doctoral final research in the field of Doctor of Ministry at the Jakarta Cross Cultural Theology College (STTLB) in 2015. This research covers the cities of Jakarta and suburban Jakarta such as Bogor, Tangerang, Depok and Bekasi.

\section{References}

[1] Allen, N. J., \& J. P. Meyer. The measurement and antecedents of affective, continuence, and normative commitment to the organization. Journal of Occupational Psychology. 63 (1990),

[2] Avolio, B.J. Transformational leadership and organizational Commitment: Mediating role of psychological empowerment New Jersey: Paulist Press, 2002

[3] Barbuto, J., \& Wheeler, D. W.. Become a servant leader: Do you have what it takes? NebGuide G02-1481-A. Lincoln: University of Nebraska, Nebraska Cooperative Extension, 2002.

[4] Blanchard, K.. Leadership by book. (New York: University of Pretoria, 2009.

[5] Darmaputera, Eka "Kepemimpinan Perspektif Alkitab" dalam Kepemimpinan Kristiani .Jakarta: STT Jakarta, 2001.

[6] Eileen Rachman \& Sylvina Savitri, Fit \& Proper . Jakarta: Gramedia Pustaka Utama, 2009.

[7] Emanuel Gerrit Singgih. Dua konteks Tafsir-tafsir Perjanjian Lama . Jakarta : BPK Gunung Mulia, 2009

[8] George Barna, A Fish out of Water. Jakarta, Immanuel ,2006

[9] George Barna . The Power of Vision: Discover and Apply God's Vision for Your Life \& Ministry Jakarta, Immanuel ,2007.

[10] Gibs, Eddie. Kepemimpinan Gereja Masa Mendatang . Jakarta: BPK Gunung Mulia, 2007. 
[11] Greenleaf, R.K.. The servant as leader. Indianapolis, IN: The Robert K. Greenleaf Center, 1996.

[12] Greenleaf, R. K.. On becoming as servant-leader. Ad. By Don M. Frick \& Larry C. Sppears. Jossey-Bass Publisher, San Fransisco, 2006.

[13] Greenleaf, R.K.. The power of servant leadership. San Fransisco: Barrett-Koehler Publisher, 2006.

[14] Greenleaf, R. K.. Servant leadership, A journey into the nature of legitimate power \& greatness. New Jersey: Paulist Press, 2002

[15] Hughes, R.L.et.al., Leadership. Boston : McGraw- Hill, 2009.

[16] Ismail, Andar. Selamat Berkiprah . Jakarta: BPK Gunung Mulia, 2002

[17] Joe E. Trull \& James E. Carter, Etika Pelayan Gereja . Jakarta: BPK Gunung Mulia, 2012.

[18] J. Riberu, Dasar-dasar Kepemimpinan .Jakarta: CV. Pedoman Ilmu Jaya, cet. ke-4, 1992.

[19] J. Dwinght Pentecost. Pertolongan Tuhan atas Persoalan Saya . Jakarta : BPK Gunung Mulia, 1974

[20] Jackson, Walter C "Church Ministry Leadership" dalam David P. Gushee dan Walter C. Jackson (ed.), Preparing for Christian Ministry. Grand Rapids, Michigan: Baker Books, 1998.

[21] Kinicki \& Kreitner. Organizational Behavio. ( New York: The McGraw Hill Companies, Inc, 2007

[22] Means, J.E. Leadership in Christian Ministry .Michigan: Baker Book House, cet.ke- 2, 1990.

[23] Northouse, Peter G. Effective Leadership. Boston : McGraw- Hill, 2009

[24] Octavianus, P., Manajemen dan Kepemimpinan Menurut Wahyu Allah . Malang: YPPII, 1997

[25] Perry, Lloyd. Getting The Church on Target . Chicago: Moody Press, cet. ke-3, 1981.

[26] Parapak, Jonathan L "Komunikasi, Elemen Dasar Kepemimpinan Kristiani" dalam Kepemimpinan Kristiani. Jakarta: CV. Pedoman Ilmu Jaya, cet. ke-4, 1992

[27] Parhusip, A.. Teologia Pertumbuhan Gereja .Pematang Siantar, 2010

[28] Rick Joyner, Kepemimpinan Kekuatan dari Hidup yang Kreatif . Jakarta : Nafiri Gabriel, 2004

[29] Robbins, Stephen P, Coulter, Mary, Manajemen 1. Jakarta: Erlangga, 2010

[30] Robbins, S.P.. Organizational behavior. 11 th Edition, New Jersey. USA: Prentice-Hall International, 2005.

[31] Roberts Liardon, Keberhasilan dalam kehidupan dan pelayanan Jakarta, Immanuel, 2001

[32] Sanders, J. Oswald Spiritual Leadership. Chicago:Moody Press, 1994.Sampurna, Budi. Kepemimpinan di Indonesia . Jakarta, Cipta Sarana, 2004.

[33] Sugiyono Wiryoputro, Dasar-Dasar Manajemen Kristiani . Jakarta: BPK Gunung Mulia, 2004

[34] Siregar, BP. "Kepemimpinan Gereja” (Paper), Medan, 20 Mei 2000.

[35] Stephen R. Covey's book, The 7 Habits of Highly Effective People, . USA: Franklin Covey, 2005

[36] Stott, John. Isu-isu Global Menentang Kepemimpinan Kristiani .Jakarta: Yayasan Komunikasi Bina Kasih/OMF, cet. ke-2, 1984.

[37] Ted W. Engstrom \& Edward R. Dayton, The Art of Management for Christians Leaders . Waco, Texas: Word Books, 1976 